\begin{tabular}{|c|c|c|c|c|}
\hline $\begin{array}{c}\text { Focus: } \\
\text { Jurnal Pekerjaan Sosial }\end{array}$ & ISSN: $2620-3367$ & Vol. 2 No: 1 & Hal: $47-60$ & Juli 2019 \\
\hline
\end{tabular}

\title{
Person in Environment Remaja Pada Era Revolusi Industri 4.0
}

\section{Wandi Adiansah' ${ }^{1}$, Eko Setiawan², Wina Nurdini Kodaruddin ${ }^{3}$ Hery Wibowo ${ }^{4}$}

\author{
1,2,3Mahasiswa Pasca Sarjana Kesejahteraan Sosial FI SI P UNPAD \\ ${ }^{4}$ Dosen Pasca Sarjana Kesejahteraan Sosial FISIP UNPAD
}

adiansahw@gmail.com, ekost92@gmail.com², winanurdini@gmail.com³, hery.wibowo@unpad.a

$$
\text { c. id }{ }^{4}
$$

\begin{abstract}
ABSTRAK
Saat ini dunia telah memasuki era revolusi industri 4.0 yang ditandai dengan semakin berkembangnya teknologi. Pada era ini, teknologi dilakukan serba digital dan serba internet. Pengguna teknologi digital dan internet ini didominasi oleh masyarakat pada kategori remaja. Secara langsung, hal ini berpengaruh terhadap remaja terutama pada aspek biologis, psikologis dan sosial. Selain itu, sejalan dengan perkembangan teknologi sistem ekologi (person in environment) remaja era revolusi industri 4.0 ini berbeda dengan sistem ekologi pada generasi sebelumnya. Tulisan ini akan menganalisis remaja pada era revolusi industri 4.0 yang selanjutnya dilihat dengan menggunakan kacamata strength based perspective guna meningkatkan keberfungsian sosial remaja tersebut. Penelitian ini dilakukan dengan menggunakan metode penelitian kualitatif deskriptif. Teknik pengumpulan data dilakukan dengan studi pustaka, studi dokumentasi dan studi penelitian terdahulu.
\end{abstract}

Kata kunci : person in environment, remaja, revolusi industri 4.0, strength based perspective.

\section{PENDAHULUAN}

Berkembangnya revolusi industri saat ini semakin mendorong perkembangan teknologi menjadi lebih maju. Dunia saat ini telah memesuki era revolusi industri 4.0. Salah satu ciri revolusi industri 4.0 ini yaitu adanya interkoneksi antara manusia dengan mesin/perangkat melalui internet of things/internet of people (Hermann, et.al:2016). Semakin berkembangnya teknologi ini tentunya berdampak luas terhadap manusia baik secara biologis, psikologis maupun sosial. Seperti dua sisi mata uang, dampak dari perkembangan teknologi pada era revolusi industri 4.0 ini pun menimbulkan dampak secara positif maupun secara negatif.

$$
\text { Perkembagan teknologi pada era }
$$

revolusi industri 4.0 ini menyebabkan hampir segala sesuatu dilakukan serba digital. Akibatnya tenaga manusia semakin tergantikan oleh robot/mesin, namun disisi lain hal ini juga menyebabkan dampak positif dalam sistem produksi yaitu dengan semakin meningkatnya tingkat efektivitas dan efisiensi produksi dan biaya yang dikeluarkan untuk produksi juga semakin rendah. Hal inilah yang menurut Tjandrawinata (2016) disebut sebagai pengaplikasian dari artificial intelligence/kecerdasan buatan dalam revolusi industri 4.0.

Salah satu perkembangan teknologi pada era revolusi industri 4.0 yaitu perkembangan teknologi komunikasi. 


\begin{tabular}{|c|c|c|c|c|}
\hline $\begin{array}{c}\text { Focus: } \\
\text { Jurnal Pekerjaan Sosial }\end{array}$ & ISSN: $2620-3367$ & Vol. 2 No: 1 & Hal: $47-60$ & Juli 2019 \\
\hline
\end{tabular}

Komunikasi yang sebelumnya dilakukan secara langsung (face to face) atau melalui media surat menyurat, telepon dan SMS (Sort Massage Service) dengan semakin berkembangnya teknologi komunikasi saat ini mulai mengalami perubahan yaitu dengan menggunkan smartphone. Berbeda dengan media komunikasi sebelumnya yang hanya dapat menyampaikan pesan berupa suara atau tulisan. Teknologi smartphone saat ini dilengkapi dengan media sosial yang tidak hanya dapat menyampaikan pesan suara atau tulisan namun juga dapat menyampaikan pesan berupa gambar, foto, video, berbagi lokasi (share location), berbagai dokumen, dll. Selain itu, melalui smartphone berbagai kebutuhan sehari-hari juga dapat dipenuhi hanya dengan sekali klik, seperti kebutuhan hiburan (entertainment), kebutuhan transportasi, pemesanan makanan, belanja online, membantu tugas sekolah, bersosialisasi melalui media sosial, hingga metode pembayaran pun saat ini mulai dikembangkan melalui metode pembayaran secara online.

Berbagai kemudahan yang ada pada smartphone yang terkoneksi dengan internet mendorong jumlah pengguna smartphone di Indonesia dari tahun ke tahun semakin meningkat. Berdasarkan laporan e-Marketer, pengguna aktif smartphone di Indonesia tumbuh dari 55 juta orang pada 2015 menjadi 100 juta orang pada 2018 ${ }^{1}$. Sementara itu, pengguna internet di Indonesia menurut Asosiasi Pengguna Jasa Internet Indonesia (APJII) pada

\footnotetext{
${ }^{1}$ https://id.beritasatu.com/home/2018-penggunasmartphone-capai-100-juta/176965
}

tahun 2017 tercatat sebanyak 143,26 juta. Jumlah ini menempatkan Indonesia berada di posisi empat dunia setelah China, India dan Amerika dalam hal pengguna internet ${ }^{2}$. Berdasarkan data tersebut, APJII juga menyatakan bahwa pengguna internet ternyata didominasi oleh usia 13-18 tahun dengan tingkat penetrasi yang mencapai 75,50\%.

Merujuk pada konsep yang dikemukakan oleh Hurlock (2002) rentang usia 13-18 tahun termasuk dalam kategori remaja. Dimana remaja pada saat ini termasuk kategori Generasi Z, yaitu mereka yang lahir pada tahun 1995-2010. Tidak dapat dipungkiri bahwa Generasi Z tersebut sejak kecil mereka sudah mengenal dan sudah terbiasa dengan berbagai bentuk gadget. Selain itu, Remaja Generasi Z ini juga lahir dan tumbuh pada saat internet sudah lebih berkembang daripada generasi sebelumnya. Hal ini menyebabkan Generasi Z telah melek internet dari semenjak mereka lahir. Hal ini secara langsung telah merubah sistem ekologi pada remaja era revolusi industri $4.0 \mathrm{ini}$.

Pada dasarnya perkembangan teknologi pada era revolusi industri 4.0 ini telah melahirkan masyarakat baru. Dalam hal ini tidak hanya masyarakat dalam arti sebenarnya (citizen), namun juga masyarakat internet atau yang disebut nettizen (Abadiano, dkk, 2014). Hal ini tentunya berpengaruh terhadap individu baik secara biologis, psikologis maupun sosiologis karena pada era revolusi industri 4.0 saat ini seorang individu memiliki dua

\footnotetext{
${ }^{2}$ https://tirto.id/jumlah-pengguna-internet-diindonesia-capai-14326-juta-pada-2017-cE3N
} 


\begin{tabular}{|c|c|c|c|c|}
\hline $\begin{array}{c}\text { Focus: } \\
\text { Jurnal Pekerjaan Sosial }\end{array}$ & ISSN: $2620-3367$ & Vol. 2 No: 1 & Hal: $47-60$ & Juli 2019 \\
\hline
\end{tabular}

lingkungan sosial yaitu lingkungan sosial secara langsung (citizen) dan lingkungan sosial di internet (nettizen). Berdasarkan hal tersebut, dapat dipahami bahwa sistem ekologi (person in environment) pada saat ini telah berkembang menjadi semakin kompleks.

Bagaimana pun sistem ekologi (person in environment) ini pada dasarnya harus mampu mendorong individu ke arah keberfungsian sosialnya. Dalam hal ini pun penting melihat individu pada sistem ekologi era revolusi industri 4.0 dengan menggunakan kacamata strength based perspective agar seluruh sistem yang ada pada individu tersebut dapat dimanfaatkan sebagai sebuah sumber daya untuk mendorong keberfungsian sosial individu. Berdasarkan latar belakang tersebut, tulisan ini akan mencoba menganalisis person in environment remaja pada era revolusi industri 4.0 yang selanjutnya dilihat dengan menggunakan kacamata strength based perspective guna meningkatkan keberfungsian sosial remaja tersebut.

\section{TI NJ AUAN PUSTAKA}

\section{Tinjauan tentang Remaja pada Era Revolusi Industri 4.0}

Masa remaja merupakan masa peralihan dari kanak-kanak untuk kemudian menjadi manusia dewasa. Pada masa ini, terdapat banyak perubahan dan perkembangan yang terjadi pada diri individu, baik biologis, psikologis, sosial, maupun spiritual. Menurut Hurlock (2002), masa remaja berlangsung dari usia 13-18 tahun. Pada masa remaja seseorang mengalami perkembangan fisik. Perubahan biologis dan perkembangan fisik pada remaja erat kaitannya dengan pubertas yang terjadi pada masa remaja, pada saat ini pertumbuhannya relatif cepat seperti pada tinggi badan, berat badan, otot otot, tulang serta pencapaian kematangan seksual (Hurlock, 2002).

Selain itu, secara kognitif, kebanyakan peneliti percaya bahwa otak sepenuhnya matang pada saat masa remaja. Perubahan dramatis dalam struktur otak remaja mencakup emosi, penilaian, perilaku organisasi, dan control diri yang berganti antara masa pubertas dan masa dewasa awal (Papalia, 2014). Perkembangan kognitif pada masa remaja juga dapat dikaitkan dengan ide yang dicetuskan oleh Piaget. Menurut Piaget (2010), pada masa remaja manusia memasuki tingkat perkembangan kognitif atau yang disebut operasi formal atau ketika mereka mengembangkan kapasitas pemikiran abstrak. Perkembangan tersebut biasanya terjadi di usia 11 tahun, memberi para remaja cara manipulasi informasi yang lebih kompleks.

Tahap kelima yang dialami individu selama tahun-tahun masa remaja menurut Erikson yaitu Identity vs identify confusion (identitas vs kebingungan identitas). Pada tahap ini mereka dihadapkan oleh pencarian jati diri siapa mereka, bagaimana mereka nanti, dan ke mana mereka akan menuju masa depannya. Satu dimensi yang penting adalah penjajakan pilihan-pilihan alternatif terhadap peran. Orangtua harus mengijinkan anak remaja menjajaki banyak peran dan berbagai jalan. Jika 


\begin{tabular}{|c|c|c|c|c|}
\hline $\begin{array}{c}\text { Focus: } \\
\text { Jurnal Pekerjaan Sosial }\end{array}$ & ISSN: 2620-3367 & Vol. 2 No: 1 & Hal: $47-60$ & Juli 2019 \\
\hline
\end{tabular}

anak menjajaki berbagai peran dan menemukan peran positif maka ia akan mencapai identitas yang positif. Jika orangtua menolak identitas remaja sedangkan remaja tidak mengetahui banyak peran dan juga tidak dijelaskan tentang jalan masa depan yang positif maka ia akan mengalami kebingungan identitas. Individu dihadapkan pada temuan siapa mereka, bagaimana mereka kira-kira nantinya, dan ke mana mereka menuju dalam kehidupannya. Sebagai persiapan ke arah kedewasaan disukung oleh kemampuan dan kecakapan yang dimilikinya dia berusaha untuk membentuk dan memperlihatkan identitas diri, ciri-ciri yang khas dari dirinya. Dorongan membentuk dan memperlihatkan identitas diri, pada remaja sering sekali sangat ekstrim dan berlebihan, sehingga tidak jarang dipandang oleh lingkungannya sebagai penyimpangan atau kenakalan.

Remaja pada saat ini merupakan kelompok yang masuk kategori Genarasi Z. Generasi $Z$ atau biasa juga disebut iGeneration ini yaitu generasi yang lahir dalam rentang tahun 1995 - 2010 (Bencsik, Csikos \& Juhaz, 2016). Generasi $Z$ merupakan generasi yang tumbuh dan berkembang dengan sebuah ketergantungan yang besar pada teknologi digital dan internet. Hal ini berhubungan dengan perkembangan era revolusi industri 4.0. Orangorang yang termasuk dalam Generasi Z sejak dini sudah mengenal atau mungkin bisa juga diperkenalkan dan terbiasa dengan berbagai macam dan bentuk gadget. Hal ini baik secara langsung atau tidak langsung sangat berpengaruh terhadap perkembangan perilaku dan kepribadiannya.

\section{Tinjauan tentang Person in Environment}

Person in Environment merupakan suatu metode untuk menjelaskan, mengklasifikasi dan koding masalah umum klien dewasa yang ditangani oleh pekerja sosial dalam proses keberfungsian sosial. Assessment dengna menggunakan PIE termasuk assessment masalah biologis, pikologis dan sosial yang berdampak pada keberfungsian sosial. Kacamata PIE membantu pekerja sosial untuk memahami keterkaitan antara manusia dan lingkungan fisik dan sosial mereka. Berdasarkan padangan PIE ini setiap individu terikat dalam sebuah sistem ekologi. Oleh karena itu, konsep PIE berusaha untuk menggabungkan ide-ide dari teori sistem umum dan ekologi. Teori sistem umum menyediakan kerangka kerja yang universal untuk membantu kita memahami kompleksitas dan keragaman perilaku manusia dan lingkungan sosialnya. Menawarkan prinsip yang menjelaskan bagaimana sistem manusia beroperasi dan berinteraksi satu sama lain. Sebaliknya, ekologi berfokus pada bagaimana semua makhluk hidup dan tumbuh bersama, bagaimana mereka beradaptasi dengan yang lain. Dalam istilah ekologi, adaptasi adalah proses yang dinamis antara manusia dan lingkungannya, seperti manusia bertumbuh, mencapai kompetensi, dan memberikan kontribusi kepada orang lain (DuBois \& Miley, 2005 : 59). 


\begin{tabular}{|c|c|c|c|c|}
\hline $\begin{array}{c}\text { Focus: } \\
\text { Jurnal Pekerjaan Sosial }\end{array}$ & ISSN: $2620-3367$ & Vol. 2 No: 1 & Hal: $47-60$ & Juli 2019 \\
\hline
\end{tabular}

\section{Tinjauan tentang Strength Based Perspective}

Strength based persperctive atau perspektif berbasis kekuatan adalah salah satu cara pandang pekerja sosial dalam memandang masalah yang dihadapi oleh klien. Perspektif ini memfokuskan pada kekuatan dan sumber daya serta meyakini bahwa setiap orang tanpa kecuali memiliki asset internal dan eksternal, kompetensi serta sumber daya (Saleebey, 2000, 127). Perspektif berbasis kekuatan mengakui bahwa individu-individu, kelompok, keluarga, organisasi, dan masyarakat mempunyai tantangan, masalah, dan kesulitan-kesulitan. Perspektif berbasis kekuatan memandang bahwa "setiap orang mempunyai sumber daya dan kapasitas untuk mengembangkan kehidupan mereka yang belum dimanfaatkan" (Saleeby dalam Graeme Stuart., 2012,1).

Menurut Healy dalam bukunya Social Work Theories in Context (2005), perspektif kekuatan berfokus pada kapasitas dan potensipotensi yang dimiliki pengguna layanan. Perspektif itu berkonsentrasi pada memampukan individu-individu dan komunitas-komunitas untuk menyampaikan dan bekerja menuju harapan masa depan mereka, ketimbang menyelesaikan masalah-masalah lalu atau yang sekarang.

Perspektif kekuatan dapat dikatakan sebagai suatu metode khusus dalam bekerjasama dengan klien serta berdasarkan pengalaman-pengalaman klien dalam mengatasi masalah-masalahnya. Hal ini bukan berarti mengabaikan kesulitan-kesulitan atau masalah- masalah yang dialami. Bahkan lebih dari itu, yaitu berupaya mengidentifikasi hal-hal positif berdasarkan sumber-sumber yang berada di seputar klien serta keterampilanketerampilannya sebagai pijakan untuk mengatasi berbagai persoalan.

\section{METODE PENELITIAN}

Metode penelitian dalam kajian ini yaitu menggunakan metode penelitian kualitatif deskriptif dengan tujuan untuk mendeskripsikan person in environment remaja pada era revolusi industri 4.0. Pengumpulan data dalam kajian ini yaitu menggunakan teknik studi pustaka dan studi penelitian terdahulu.

\section{HASI L DAN PEMBAHASAN}

Remaja pada era revolusi industry 4.0 termasuk dalam kategori generasi Z. Generasi Z merupakan generasi yang tumbuh dan berkembang dengan sebuah ketergantungan yang besar pada teknologi digital dan internet. Orang-orang yang termasuk dalam Generasi Z sejak dini sudah mengenal atau mungkin bisa juga diperkenalkan dan terbiasa dengan berbagai macam dan bentuk gadget. Hal ini baik secara langsung atau tidak langsung sangat berpengaruh terhadap perkembangan perilaku dan kepribadiannya, Sudah jamak bahwa media membawa efek pada perilaku. Kecepatan internet telah membuat perilaku Gen Z sangat berbeda dengan generasi sebelumnya. Mereka suka akan sesuatu yang instan, cepat, kolaboratif, dan viral. Beda dengan orangtua mereka, ayah-ibu mereka yang bergen $X$ atau $Y$ 


\begin{tabular}{|c|c|c|c|c|}
\hline $\begin{array}{c}\text { Focus: } \\
\text { Jurnal Pekerjaan Sosial }\end{array}$ & ISSN: $2620-3367$ & Vol. 2 No: 1 & Hal: $47-60$ & Juli 2019 \\
\hline
\end{tabular}

adalah generasi yang merasakan kecepatan internet di tahap pertengahan dalam hidup, mereka sempat merasakan hegemoni media koran dan buku-buku fisik sehingga mereka masih bisa sabar dan mengendalikan diri. Sedangkan gen Z, mereka melek internet dari sejak lahir.

Efek perilaku instan yang dibawa oleh internet membuat gen $\mathrm{Z}$ terkadang kurang berkomunikasi secara langsung, secara verbal. Mereka lebih terbiasa berkomunikasi via media sosial. Sayangnya, relasi mereka yang terjalin kuat dengan dunia maya melalui media sosial membuat mereka seringkali terputus konektivitas dengan dunia nyata. Intensitas pertemuan fisik berkurang, meet up yang biasa dilakukan saat ini tinggal wacana, ada fenomena menarik di sini. Karena mereka terbiasa bebas berbicara di medsos, maka timbul rasa canggung ketika terjadi pertemuan fisik, yang ujung-ujungnya mereka bersama-sama melihat dan tenggelam dalam gadget mereka masingmasing dan berbagi fokus antara dunia maya dalam gadget yang tergenggam dan dunia nyata dengan orang di hadapan mereka.

Jika dilihat dari gaya hidup remaja saat ini cenderung hedonis terutama di kota-kota besar, mereka memiliki cara tersendiri untuk meluapkan ekspresi mereka, dunia hidup mereka tidak bisa lepas dari hiburan dan teknologi terutama internet (media sosial). Media sosial telah menjadi bagian dari keseharian mereka untuk dapat melihat perkembangan baru dari teman begitu pula sebaliknya, yaitu membagikan perkembangan kehidupan diri kepada teman.

Perkembangan teknologi digital yang semakin canggih dan budaya komunikasi dengan media social memunculkan fenomena perilaku remaja seperti nomophobia dan phubing. Nomophobia (no mobile phone phobia) merupakan istilah untuk menggambarkan seseorang yang tidak bisa jauh dari media social. Jenis fobia yang ditandai ketakutan berlebihan jika seseorang kehilangan dari ponsel untuk sekedar melihat notifikasi yang masuk. Mereka akan selalu membawa kemanapun pergi dan hampir selalu memeriksa ponselnya setiap ada kesempatan. Ketakutan akan kehabisan baterai, sinyal dan melewatkan panggilan telepon atau sms serta informasi penting dalam media social juga merupakan bentuk nomophobia. Phubing adalah gabungan dari kata phone dan snubbing, menurut Haigh (2015) diartikan sebagai tindakan menyakiti orang lain dalam interaksi sosial karena lebih berfokus pada smartphonenya. Karadag, et, al (2015) menyebutkan bahwa Phubbing dapat digambarkan sebagai individu yang melihat telepon genggamnya saat berbicara dengan orang lain, sibuk dengan smartphonenya dan mengabaikan komunikasi interpersonalnya.

\section{Analisis Person in Environment Remaja pada Era Revolusi Industri 4.0}

Karakteristik dan perilaku remaja (Generasi Z) pada era revolusi industri 4.0 tidak hanya faktor dari dalam diri saja, namun juga dipengaruhi oleh factor lingkungan yang 


\begin{tabular}{|c|c|c|c|c|}
\hline $\begin{array}{c}\text { Focus: } \\
\text { Jurnal Pekerjaan Sosial }\end{array}$ & ISSN: $2620-3367$ & Vol. 2 No: 1 & Hal: $47-60$ & Juli 2019 \\
\hline
\end{tabular}

berpengaruh dalam pembentukan karakteristik dan perilaku remaja saat ini. Perspektif ekologis mempertimbangkan kemampuan adaptif kehidupan manusia dan lingkungannya yaitu, ekologi manusia dalam "life space’hya. Yang termasuk semua komponen lingkungan sosial dan fisik yang berdampak kepada mereka. Sebuah perspektif ekologis menekankan pentingnya mengkaji person in evnvironment (PIE). Dengan begitu suatu assessment fokusnya tidak hanya manusia tetapi juga sistem lingkungan yang berdampak pada kehidupannya.

Person in environment melaksanakan beberapa prinsip yang mendasari pekerjaan sosial modern yaitu interaksi manusia dengan lingkungan. Minahan dalam Roberts (2008) menyatakan bahwa dalam melaksanakan tujuannya di masyarakat, pekerja sosial meningkatkan atau mengembalikan interaksi timbal balik yang saling menguntungkan antara individu dan masyarakat, memfasilitasi interaksi antara individu dan orang lain dalam lingkungannya, membantu manusia meningkatkan kompetensi dan kemampuannya dalam menangani dan mengatasi masalah, mempengaruhi kebijakan sosial dan lingkungan. Perspektif manusia dalam lingkungan sosial bertujuan menciptakan manusia untuk berfungsi sosial.

Struktur dari person in environment terdiri dari empat factor sistem yaitu factor peran sosial dalam hubungan dengan orang lain, faktor lingkungan sosial, factor kesehatan mental dan factor kesehatan fisik. Berkaiatan dengan perspektif person in environment, permasalahan yang dialami remaja pada era revolusi industri 4.0 sangat kompleks karena lingkungan sosial yang diciptakan tidak hanya pada dunia nyata namun juga pada dunia maya yang pengaruhnya cukup signifikan bagi remaja. Struktur PIE remaja akan mempengaruhi bagaimana keberfungsian sosialnya.

Lingkungan sosial remaja dapat meliputi hubungan dalam keluarga yang terdiri dari orang tua, kakak, adik, saudara. Kemudian hubungan dengan kekasih, teman, tetangga, kelompok bermain/geng. Peran sosial remaja sebagai pelajar di sekolah, organasisasi kesiswaan di lingkungan sekolah, organisasi remaja/pemuda di lingkungan masyarakat, komunitas hobi, dan kelompok-kelompok lain. Seorang remaja harus mampu berperan dalam berbagai relasi sosial yang berbeda-beda. Selain relasi sosial dalam kehidupan nyata, juga terdapat relasi sosial di dunia maya melalui media sosial. Berbagai aplikasi media sosial kini muncul dan rutin diakses oleh remaja seperti facebook, twitter, instagram, whatsaap, line, dll. Hampir sebgaian besar remaja memiliki akun dari media sosial tersebut dan bahkan setiap aplikasi media sosial tidak hanya satu akun tetatpi bisa lebih dari satu akun. Menurut penelitian yang dilakukan We Are Social, perusahaan media asal Inggris yang bekerja sama dengan Hootsuite, rata-rata orang Indonesia menghabiskan 3 jam 23 menit sehari untuk mengakses media sosial. Berdasarkan data BPS, dari 143 juta jiwa anak muda, 54 persen itu sudah menggunakan internet. 90,61 


\begin{tabular}{|c|c|c|c|c|}
\hline $\begin{array}{c}\text { Focus: } \\
\text { Jurnal Pekerjaan Sosial }\end{array}$ & ISSN: $2620-3367$ & Vol. 2 No: 1 & Hal: $47-60$ & Juli 2019 \\
\hline
\end{tabular}

persen anak muda masih memanfaatkan internet hanya untuk media sosial dan jejaring sosial. Hal ini menunnjukkan bahwa penggunaan media sosial pada remaja sangat tinggi. Penggunaan sosial media yang tinggi pada remaja juga mengakibatkan interaksi dalam lingkungan sosial di dunia nyata semakin berkurang.

Masa remaja adalah masa yang berpengaruh dalam pembentukkan self concept seseorang. Seorang anak akan semakin banyak berinteraksi dengan lingkungannya dan bukan hanya ia memberi arti pada lingkungannya tersebut, tetapi ia juga akan menerima banyak masukan dari lingkungan itu sendiri. Tanggapan dari orang lain mengenai dirinya maupun pandangan dirinya terhadap tanggapan orang lain tentang dirinya juga akan membawa dampak tersendiri, yang semuanya akan memberi sumbangan dalam pembentukkan self concept seorang remaja. Selain itu mereka juga butuh membentuk ikatan yang kuat dengan teman sebayanya, merasa disukai, dicintai, dan dihargai. Namun, pada era revolusi industry 4.0 self concept remaja dibangun tidak hanya dari hubungan yang terjadi di dunia nyata tetapi self concept remaja sangat dipengaruhi oleh hubungan dan interaksi yang terjadi di dunia maya melelui media sosial. Tanggapan dari orang lain di media sosial baik like maupun komentar akan membentuk self conceptremaja. Remaja yang mendapatkan banyak like dan komentar yang positif pada postingannya akan merasa disukai dan dihargai sehingga self esteem nya tinggi. Sedangkan remaja yang mendapat like sedikit dan komentar negatif akan mengakibatkan mereka merasa buruk, tidak disukai dan dihargai sehingga self esteemnya akan rendah. Self esteem yang tinggi maupun rendah ini akan mempengaruhi self concept remaja apakah akan menjadi positif atau negatif.

Penggunaan media sosial dilihat oleh remaja sebagai salah satu wadah yang dapat membantu penemuan identitas dirinya. Melalui media sosial, remaja memiliki komunitas online yang memberikan kesempatan bagi remaja untuk berinteraksi secara sosial dengan orang lain dan mendapatkan umpan balik tentang dirinya dari komunitas tersebut. Pembentukan self concept sangat dipengaruhi oleh lingkungan dan umpan balik yang individu terima dari lingkungannya. Umpan balik dan evaluasi diri dari komunitas dunia maya ini dianggap penting bagi individu untuk dijadikan pedoman membentuk konsep dirinya. Selain itu, komunikasi melalui dunia maya tidak terlalu membebani dan menakutkan bagi remaja karena remaja dapat mengganti karakternya secara mudah pada media sosial. Dengan kata lain, bagi para remaja komunikasi dunia maya melalui media sosial dianggap sebagai tempat ideal untuk bereksperimen dan melakukan eksplorasi pencarian identitas. Dikarenakan kemudahan dalam menjelajahi dunia media sosial, remaja mengakses media sosial secara terus menerus dan seringkali menimbulkan fenomena penggunaan berlebihan atau ketagihan (addiction). 


\begin{tabular}{|c|c|c|c|c|}
\hline $\begin{array}{c}\text { Focus: } \\
\text { Jurnal Pekerjaan Sosial }\end{array}$ & ISSN: 2620-3367 & Vol. 2 No: 1 & Hal: $47-60$ & Juli 2019 \\
\hline
\end{tabular}

Remaja menurut tahap perkembangan Erikson sedang berada pada tahap kelima yaitu tahap identitas vs kekacauan identitas (identity versus identity confusion) dimana para remaja sedang berusaha untuk mencari dan mendefinisikan dirinya sendiri. Erikson mengatakan bahwa masa remaja merupakan jarak (gap) antara rasa aman pada masa anakanak (childhood security) dan kemandirian yang harus dimiliki pada masa dewasa (adult autonomy). Pada masa ini, para remaja diberikan kebebasan secara bertanggung jawab, sehingga para remaja memiliki kesempatan untuk mencoba berbagai macam identitas diri yang dimilikinya. Para remaja bereksperimen dengan sejumlah peran (role) dan kepribadian (personality) yang berbeda-beda. Mereka sangat mungkin untuk memiliki sebuah cita-cita untuk mengejar suatu karir, kemudian cita-cita tersebut berubah di lain waktu. Eksperimen ini dilihat sebagai suatu upaya yang disengaja, sebagai bagian dari tahap pencarian jati diri para remaja. Pada akhirnya para remaja akan mengabaikan peran dan kepribadian yang kurang sesuai dengan identitas diri mereka (Santrock, 2014). Jika remaja berhasil menyelesaikan tahap ini, ia akan menemukan yang disebut sebagai "identitas diri", namun jika gagal remaja akan mengalami kesulitan untuk mendefinisikan dirinya sendiri (identity confusion). Identity confusion ditandai dengan sikap remaja yang mengisolasi dirinya sendiri dan berusaha menghindar dari kelompok temantemannya dan keluarga. (Santrock, 2014).
Dalam usaha menemukan identitas, remaja membutuhkan teman sebaya. Remaja butuh menunjukan keberadaan dirinya, menunjukkan siapa dirinya, dan membutuhkan pengakuan dari lingkungannya. Pada era revolusi industry 4.0 lingkungan sosial media sangat berpengaruh dalam pembentukan identitas diri remaja. Melalui kata-kata, gambar/foto, video yang di posting di media sosial remaja berusaha untuk menunjukkan identitas dirinya. Reaksi postif dari netizen akan memperkuat identitas diri remaja sebaliknya reaksi negatif dari netizen akan membuat remaja mengalami identity confusion karena kurang mendapat pengakuan dan dukungan dari orang lain. Selain itu, sosial media menjadi referensi bagi remaja dalam mencari identitas dirinya. Mereka akan mengikuti figur yang diidolainya di media sosial. Mereka akan meniru segala seuatu yang ditampilakan idolanya di media sosial. Figure idolanya ini akan menjadi role model bagi remaja dalam menemukan identitas dirinya.

\section{Analisis Strength Based Perspective Pada Remaja Era Revolusi Industri 4.0}

Perspektif berbasis kekuatan adalah proses membantu individu, keluarga, kelompok, dan komunitas untuk meningkatkan kekuatan pribadi, interpersonal, sosial ekonomi dan politik mereka dan mengembangkan pengaruh terhadap perbaikan keadaan mereka (Barker: 1995).

Seorang pekerja sosial dalam melakukan proses pertolongan pada kliennya harus 


\begin{tabular}{|c|c|c|c|c|}
\hline $\begin{array}{c}\text { Focus: } \\
\text { Jurnal Pekerjaan Sosial }\end{array}$ & ISSN: $2620-3367$ & Vol. 2 No: 1 & Hal: $47-60$ & Juli 2019 \\
\hline
\end{tabular}

berfokus pada masalah serta tidak melakukan labeling pada klien. Asesmen berbasis kekuatan dapat dilakukan oleh seorang pekerja sosial berfokus pencapaian klien, sumber daya yang tersedia untuk klien, pengetahuan dan bakat klien, serta aspirasi dan impian klien.

Berkaitan dengan fenomena remaja di era 4.0, sebagai pekerja sosial kita dapat melakukan asesmen berbasis kekuatan sehingga dapat memberikan solusi pada permasalahan remaja dengan meningkatkan serta memaksimalkan kekuatan di diri dan lingkungan klien serta meminimalisir kelemahan di diri dan lingkungan klien.

Kekuatan remaja Ditinjau dari aspek biologis atau fisik, remaja masa kini cenderung memiliki tubuh yang kuat. Hal ini didasarkan pada asupan gizi remaja yang baik, mereka dapat melakukan banyak aktivitas fisik serta olahraga yang memerlukan kekuatan dan kebugaran. Minat serta potensi remaja di bidang olahraga pun banyak diakui masyarakat, seperti Timnas Sepakbola U-16 yang menjuarai Piala AFF 2018.

Sementara aspek psikologis, kini remaja cenderung ekstrovert dan memiliki kepercayaan diri yang tinggi. Mereka lebih dapat mengungkapkan apa yang mereka rasakan serta fikirkan baik pada teman sebaya, orang tua, maupun pada khalayak ramai di sosial media yang mereka miliki. Begitupula dengan kepercayaan diri, mereka lebih berani untuk tampil di depan umum serta memiliki sikap optimis atas kemampuan yang mereka miliki.
Aspek sosial remaja masa kini tampak pada kemampuan adaptasi mereka yang baik, serta mudahnya mereka membentuk pertemanan dengan orang baru. Berkembangnya berbagai jenis sosial media menjadikan remaja lebih aktif berkomunikasi dengan banyak orang hal ini menyebabkan mereka mudah membentuk pertemanan juga beradaptasi jika harus bergaul dengan orang atau tempat yang baru.

Intelegensi remaja pun berkembang, mereka memiliki daya tangkap yang baik, pengetahuan yang lebih luas, dan rasa ingin tahu yang tinggi. Sejak kanak kanak mereka sudah sering berinteraksi dengan internet, mereka dapat dengan cepat mengoperasikan handphone dibnding orang dewasa lainnya.

Selain kekuatan, terdapat pula kelemahan remaja masa kini diantaranya dari aspek psikologis. Mereka masih cenderung memiliki emosi yang tidak stabil bahkan sering meluap-luap, seringkali terjadi perkelahian antar remaja karena hal-hal yang sebenarnya tidak terlalu besar. Mereka pun belum dapat bertanggung jawab penuh dengan apa yang telah dikerjakannya. Misalnya kenakalan remaja berupa mencuri, mereka seringkali tidak berfikir panjang apa saja dampak yang akan terjadi setelah mereka mencuri. Remaja pun mudah terpengaruh oleh teman atau hal hal yang sebenarnya tidak sesuai dengan norma, seperti kebiasaan merokok yang bermula diajak teman juga meniru - niru pakaian seperti orang luar negeri, padahal tidak sesuai dengan budaya ketimuran. 


\begin{tabular}{|c|c|c|c|c|}
\hline $\begin{array}{c}\text { Focus: } \\
\text { Jurnal Pekerjaan Sosial }\end{array}$ & ISSN: $2620-3367$ & Vol. 2 No: 1 & Hal: $47-60$ & Juli 2019 \\
\hline
\end{tabular}

Sementara dari aspek sosial, tata karma remaja saat ini cenderung berkurang. Tidak jarang di media kita melihat remaja yang berkelahi dengan gurunya, atau berani memukul orang tuanya. Remaja membentak atau melawan pada orang tua dan guru sangat sering terjadi di sekitar kita.

Remaja masa kini pun kurang peka terhadap lingkungan sosial di dunia "nyata" mereka, tidak jarang kita menemui remaja yang saat ini lebih betah didalam rumah untuk bermain gadget daripada ikut perkumpulan remaja seperti karang taruna. Sehingga mereka seringkali tidak mengenal tetangga yang tinggal di sekitaran rumahnya, khususnya remaja yang tinggal di kota besar.

Bagi seorang pekerja sosial, lingkungan pun menjadi faktor yang sangat berpengaruh bagi penanganan masalah klien. Dalam mengatasi fenomenan remaja kekuatan dari lingkungan perlu dimanfaatkan diantaranya kemudahan akses teknologi digital berupa internet, perkembangan gadget sehingga mudah mendapat informasi. Ketika disikapi dengan positif, maka hal ini dapat membuat remaja lebih cerdas, menambah pengetahuan, serta membuka wawasan tentang dunia luar.

Sistem pendidikan pun sudah semakin maju, kurikulum pendidikan yang didapat remaja di sekolah pun terus berkembang. Dengan kemajuan pendidikan, seharusnya terlahir juga remaja yang cerdas serta memiliki kompetensi yang baik. Sehingga remaja sebagai generasi penerus bangsa yang mumpuni di berbagai ilmu serta memiliki karakter yang baik.
Di Indonesia saat ini banyak pula program untuk pengembangan kompetensi dan bakat remaja. Bagi remaja yang berminat di bidang akademik, terdapat program pertukaran pelajar, bidik misi untuk menempuh pendidikan di perguruan tinggi bagi remaja kurang mampu, serta beragam beasiswa pendidikan lainnya. Begitupula bagi remaja yang setelah lulus SMA memiliki keinginan untuk bekerja, terdapat program pelatihan kerja di BLK (Balai Latihan Kerja) yang ada di setiap Provinsi. Sementara untuk remaja yang berbakat di bidang seni, saat ini banyak pula ajang pencarian bakat yang dapat menjadi sarana bagi remaja menyalurkan bakatnya untuk menjadi entertainer professional.

Dengan perkembangan zaman, mempengaruhi juga faktor lingkungan. Kelemahan factor lingkungan diantaranya melemahnya kontrol sosial masyarakat terhadap remaja, masyarakat kini seringkali kurang peka dalam menangkap fenomena yang mencurigakan yang terjadi pada remaja serta membiarkan semisal ada remaja berpacaran yang berduaan di tempat sepi karena menganggap cukup aman seperti dulu.

Selain itu, ikatan antar keluarga pun melemah sehingga penghormatan anak pada orangtua berkurang bergitu pula kasih sayang orang tua pada anak. Padahal keluarga merupakan pondasi utama dalam menanamkan moral dan etika bagi anak remaja.

Analisa terhadap kekuatan ini merupakan hal yang penting dilakukan guna pekerja sosial bersama klien menentukan 


\begin{tabular}{|c|c|c|c|c|}
\hline $\begin{array}{c}\text { Focus: } \\
\text { Jurnal Pekerjaan Sosial }\end{array}$ & ISSN: $2620-3367$ & Vol. 2 No: 1 & Hal: $47-60$ & Juli 2019 \\
\hline
\end{tabular}

prioritas perubahan dengan mengkaji kekuatan

untuk meningkatka keberfungsian sosialnya.

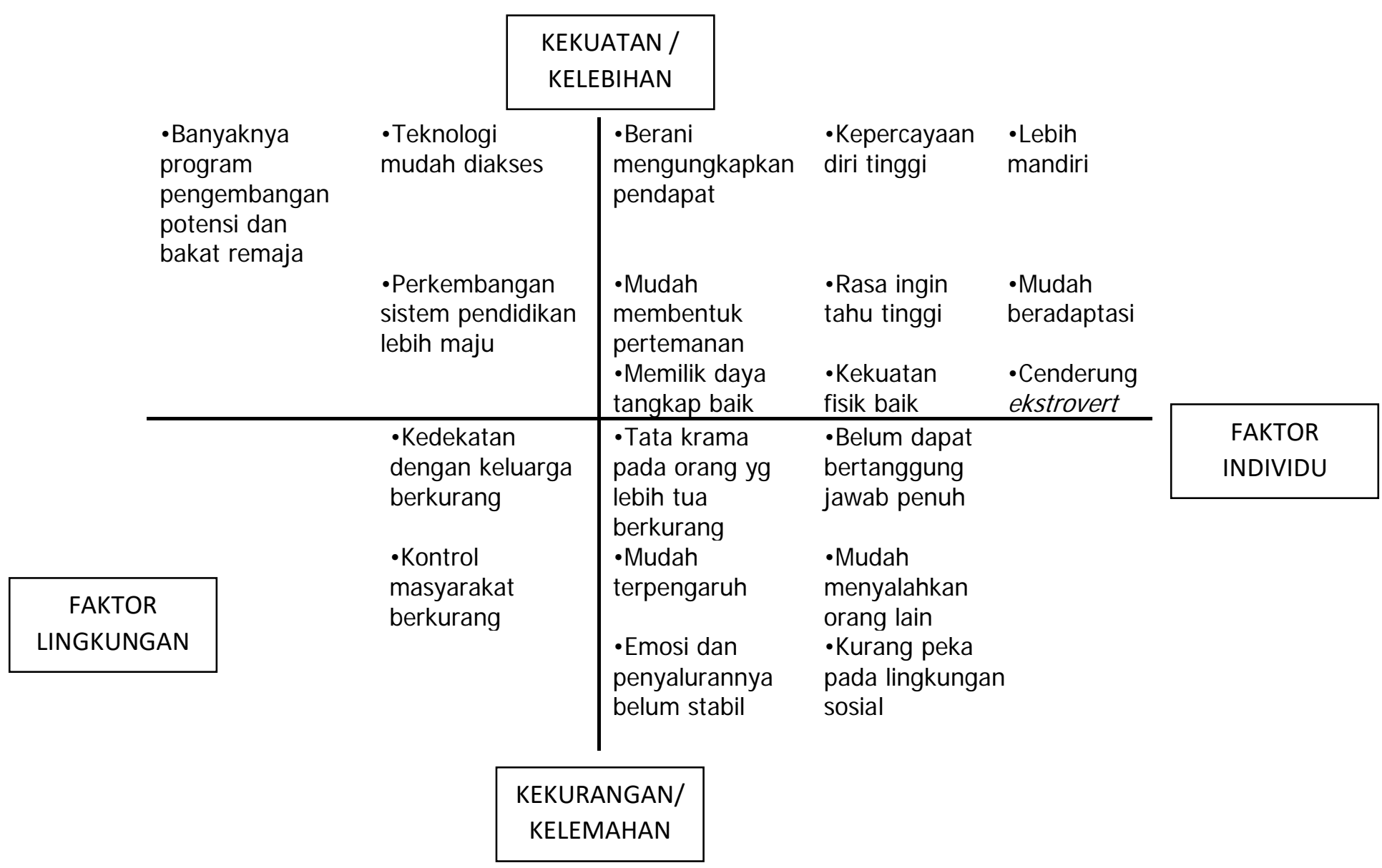

\section{KESI MPULAN DAN SARAN}

\section{KESI MPULAN}

1. Dengan PIE, asesmen tidak hanya memandang individu itu saja namun juga melihat bagaimana lingkungan sosial mempengaruhi kehidupannya. Lingkungan sosial remaja pada era revolusi industri 4.0 terdiri dari lingkungan di dunia nyata dan lingkungan di dunia maya melalui sosial media. Tingginya tingkat penggunaan sosial media pada remaja mengakibatkan interaksi remaja dengan lingkungan dunia nyata semakin berkurang. Lingkungan sosial berpengaruh dalam membentuk self concept remaja. Remaja pada saat ini lebih dipengaruhi lingkungan sosial media dalam pembentukan self concept nya. Termasuk juga dalam pencarian identitas diri remaja dilakukan melalui sosial media. Reaksi positif dari netizen akan memperkuat dan mendukung identitas diri remaja. Sebaliknya, reaksi negatif netizen akan mengakibatkan identity confusion pada remaja.

2. Dengan strength based, pekerja sosial memandang remaja sebagai kesatuan 


\begin{tabular}{|c|c|c|c|c|}
\hline $\begin{array}{c}\text { Focus: } \\
\text { Jurnal Pekerjaan Sosial }\end{array}$ & ISSN: $2620-3367$ & Vol. 2 No: 1 & Hal: $47-60$ & Juli 2019 \\
\hline
\end{tabular}

manusia yang utuh dan unik. Efek modernisasi dan perkembangan teknologi dapat dijadikan kekuatan saat remaja menggunakannya dengan bijak dan mengambil manfaat yang ada didalamnya. Begitupula dengan remaja yang secara individu menjadi lebih percaya diri, mudah beradaptasi, dan berani menyampaikan pendapat, hal hal positif ini perlu ditingkatkan guna membentuk kepribadian remaja yang positif.

\section{SARAN}

1. Masa remaja memerlukan banyak perhatian dari orangtua dan keluarga secara khusus serta masyarakat secara umumnya.

2. Orangtua dan Keluarga memberikan perhatian dan pengawasan terhadap aktivitas anak di dalam maupun diluar rumah, begitu juga dengan interaksi remaja dengan citizen di media sosialnya.

3. Sekolah. Sebagai tempat dimana remaja banyak menghabiskan waktu, sekolah

\section{DAFTAR PUSTAKA}

Abadiano, Mark N.; Bonotan, Amelia \& Makiling, Rossa V. 2014. The Dynamics Of Netizen's Information-Sharing In Social Media: Why Do We Share Information In Social Media?, International Journal of Interdiciplinary Research \& Innovations, Vol.2, Issue 3, PP: (30-55), Month: J uly 2014-September 2014.

Bencsik, A., Csikos, G., \& Juhaz, T. (2016). Y and Z Generations at Workplaces. J ournal of Competitiveness, 8(3), 90106. https://doi.org/10.7441/joc. 2016.03.06

Dubois, Brenda and Miley, Karla Krogsrud. 2005. Social Work, An Empowering Profession. Boston: Pearson Education, Inc. sebaiknya memberikan juga pendidikan karakter, moral dan etika agar remaja siap berintegrasi dalam masyarakat dengan baik. Termasuk didalamnya, etika dalam menggunakan teknologi dan media sosial, pendidikan ini dapat dilakukan secara khusus oleh pekerja sosial sekolah maupun guru BK.

4. Masyarakat diharap memberikan kontrol sosial pada remaja, hal ini dapet berguna sebagai preventif sebelum terjadi masalah sosial remaja di masyarakat. Selain itu diperlukan juga pelibatan remaja di dalam kegiatan kemasyarakatan diharap dapat membuat remaja merasa dianggap eksistensinya dan mampu menyalurkan aspirasinya.

5. Pemerintah. Program program pemberdayaan remaja semakin diperbanyak, hal ini perlu agar remaja memiliki lebih banyak pilihan media untuk mengembangkan diri, potensi serta bakat yang mereka miliki.

Felita, Pamela dkk. 2016. Pemakaian Media Sosial dan Self Concept pada Remaja. J urnal IImiah Psikologi MANASA. Vol. 5. No. 1. Hal. 30-41.

Healy, Karen 2005 Social Work In Context: Creating Framework for Practice. New York: Palgrave Mc Millan.

Hermann, M., Pentek, T., \& Otto, B. (2016). Design Principles for Industrie 4.0 Scenarios. Presented at the 49th Hawaiian International Conference on Systems Science.

Hurlock, E.B (2002). Psikologi Perkembangan. 5th edition. Erlanga: Jakarta.

Kurniawan, Harso dan Syukra, Ridho. 2018. 2018 Pengguna Smartphone Mencapai 100 juta.

Diunduh 


\begin{tabular}{|c|c|c|c|c|}
\hline $\begin{array}{c}\text { Focus: } \\
\text { Jurnal Pekerjaan Sosial }\end{array}$ & ISSN: $2620-3367$ & Vol. 2 No: 1 & Hal: $47-60$ & Juli 2019 \\
\hline
\end{tabular}

dari https://id. beritasatu.com/home/2018pengguna-smartphone-capai-100juta/176965 pada tanggal 16 Desember 2018 pukul 14.49 WIB.

Kusuma, Wahyunanda. 2018. Riset Ungkap Pola Pemakaian Medsos Orang Indonesia melalui <https://tekno.kompas.com/read/ 2018/03/01/10340027> (03-01-2018)

Mamduh, Naufal. 2018. Jumlah Pengguna Internet di Indonesia Capai 143,26 Juta pada 2017. Diunduh dari https://tirto.id/jumlah-penggunainternet-di-indonesia-capai-14326-juta-pada2017-cE3N pada tanggal 16 Desember 2018 pukul 15.32 WIB.

Merdeka.com. 2018. "90 persen anak muda di Indonesia gunakan internet untuk media sosial". melalui $<$ https://www.merdeka.com/peristiwa/.ht $\underline{m l}>$ (31-03-2018).

Papalia, E. D. dan Feldman, R. T. (2014). Meyelami Perkembangan Manusia ; Experience Hman Development. Jakarta: Salemba Humanika.

Piaget, J ean, \& Barbel Inhelder, 2010. Psikologi Anak. Pustaka Pelajar: Yogyakarta.
Rabathy, Qisthy. 2018. Nomophobia Sebagai Gaya Hidup Mahasiswa Generasi Z. Jurnal Linimasa. Vol.1 No. 1. Hal 33-44.

Roberts, Albert R. \& Greene, Gilbert J. 2008. Buku Pintar Pekerja Sosial. Jakarta: Gunung Mulia.

Saleebey, Dennis. 2000, Poer in The People; Strengths and Hope, in Advances in Social Work, Vol, 1 No. 2, Indiana University School of Social Work.

Santrock, J hon W. 2014. A Topical Approach Life Span Development. $7^{\text {th }}$. New York : McGraw-Hill Education.

Stuart, Graeme. 2012. What is Strengths Perspective. Sustaining Community.

Tjandrawinata, R.R. (2016). Industri 4.0: Revolusi industri abad ini dan pengaruhnya pada bidang kesehatan dan bioteknologi. Jurnal Medicinus, Vol 29, Nomor 1, Edisi April.

Younarti, Inta Elok \& Nur Hidayah. 2018. Perilaku Phubing Sebagai Karakter Remaja Generasi $Z$ Jurnal Fokus Konseling. Vol. 1 No. 1 Hal. 142-153. 